\title{
Introduction
}

\section{THE JEWISH COMMUNITIES OF LATIN AMERICA}

7 he history of the Jews in Latin America is marked by contradictions. During 1 the colonial era, the Spanish and Portuguese monarchies prohibited any Jewish presence, but the Jews were able to create modern Jewish communities in the Dutch and British Caribbean. The Inquisition persecuted crypto-Jews, and their descendants were assimilated into the Catholic societies. In recent years, however, we have witnessed the proliferation of groups that consider themselves Bnei anusim (descendants of marranos), around Recife-which was part of the Dutch colony in Brazil, as well as in Peru, Mexico and Colombia.

The first Jewish immigrants to reach the Latin American republics after independence settled in the Caribbean port cities of Venezuela, Colombia, and Panama. They prospered economically, but tended to intermarry and assimilate. Their traces, however, did not disappear, and, in some cases, they laid the foundations for the future organization of their respective communities.

The forerunners of the Sephardic communities in Brazil were Moroccan Jews from Tétouan and Tangier, who immigrated during the nineteenth century, and penetrated into the Amazon region as a result of the rubber boom. The decline of the rubber industry brought many of them to Rio de Janeiro and São Paulo. In recent years, groups of Amazonians of Moroccan descent have reclaimed their Jewish identity.

During the period of mass migration, the countries of the Southern Cone-Argentina, Brazil, Uruguay, and Chile-tried to attract European immigrants, especially agricultural workers. Argentina thus became the focus of an organized attempt to solve the problem of Russian Jewry through a massive agricultural project sponsored by Baron Maurice Hirsch. The agricultural colonies became a hotbed nurturing the leadership of Jewish Argentina, and provided the narrative of the local roots of the "Jewish Gauchos," but, from a practical point of view, Jewish agriculture disappeared within two generations. 
Nevertheless, the Jewish agricultural settlements, which today house a very small number of Jews, did not escape from a new form of contemporary Jewish identity. Thus, in recent decades, the colonies created by Baron Hirsch have been transformed into memory landmarks of the Argentine Jewish community. We may claim, then, that they operate as the foundational myth of the Argentine Jewish community, competing with other myths of origin and "mother lands," such as Eretz Israel or the communities in Europe and the Middle East, from which the first immigrants to Argentina arrived. Jewish schools organize visits to these colonies and small villages, and there are organized tours for members of the Jewish communities and the general Argentine public. These demonstrate the ability of the largest Jewish community of Latin America to recreate its Judaism, incorporating its Jewish past into the history of Argentina as well as to its Jewish present through creative strategies.

With the decline of the Ottoman Empire, Sephardic Jews began to immigrate to Latin America in large numbers. Jews from Syria, Turkey, and the Balkan countries dispersed throughout the continent since the beginning of the twentieth century, establishing communal infrastructures based on sub-ethnic affiliation.

During the 1920s, large numbers of Jews from Poland and other East European countries immigrated to Latin America. From a historical perspective, the United States quota acts led to Latin America becoming a destination for Jewish mass migration. The closing of the gates of America resulted in the growth of the Jewish communities in the Southern Cone, as well as in Mexico and Cuba. During the Holocaust, the countries of Latin America became potential havens for Jewish refugees from countries under Nazi rule, creating a contradiction between law and practice: while all the countries implemented a restrictive legislation that legally closed their gates, they did not necessarily deny unofficial procedures for rescue. In fact, there is no correlation between the capacity for absorption and the number of refugees who entered each country. ${ }^{1}$

Jewish institutional life was established on a voluntary basis, and was influenced by the model of the communities of origin as well as by the different circumstances in the new countries. Larger communities were able to create more elaborate infrastructures, but the patterns of organization were similar. The Ashkenazi Jews created religious institutions, even though most of them

1 Haim Avni, "The Spanish Speaking World and the Jews, the Last Half Century," in Terms of Survival: The Jewish World since 1945, ed. Robert S. Wistrich (Abingdon, UK: Routledge, 1995), 358-82; "Latin America and the Jewish Refugees: Two Encounters, 1945 and 1938," in The Jewish Presence in Latin America, ed. Judith Laikin Elkin and Gilbert W. Merkx (Boston: Allen and Unwin, 1987), 58-68. 
$\mathbf{x} \mid$ Introduction

were secular. They developed educational networks, as well as social and cultural institutions that reflected the political conflicts between Zionists, Bundists, and Communists. The Landsmanschaftn (institutions for persons coming from the same town) characterized the first generation, and were substituted gradually by a general Ashkenazi identity, unlike the Sephardic Jews, who tended to preserve sub-ethnic divisions. The Sephardic institutions are based on centralized communities that maintain divisions between Ladino speakers, Aleppans (Halebis), Damascenes (Shamis), and Moroccans.

The Judaism of the immigrants, which differed significantly from the Judaism recreated by the first and second generations born in Latin America, reveals rich and complex phenomena in the social, political, religious, and cultural development of the Jewish communities from different countries. Social, cultural, and political transitions challenged the institutional infrastructures created by the immigrant generation. Processes of integration and assimilation were influenced by the ethnic composition and attitudes toward religious diversity and multiculturalism that require specific analysis for each individual country. Intergenerational conflicts, mixed marriages, and the growing identification with the non-Jewish environment alienated large segments of the Jewish population from the organized communities, especially in countries with large European populations and with an ideological openness toward pluralism-Brazil being a paradigmatic case. In countries with large indigenous populations, such as Mexico and Peru, where immigrants and their descendants were small minorities, the Jews tended to be auto-segregated in their own communities, and, to this day, are more involved in communal life.

For many years, the Jews of Latin America-particularly the Ashkenazi Jews - tended to be secular. From the 1940s on, Jewish identity was constructed around two axes: Zionism and the Holocaust. In the words of historian Judith Laikin Elkin, the Jews of Latin America were "a secular minority attached to Zionism as a substitute for its ancestral religion." 2 This situation has changed totally in the last fifty years. The Conservative movement became a focus of religious attraction that spread from Argentina throughout the continent, converting the Seminario Rabínico de Buenos Aires into an exporter of rabbis to all the Spanish-speaking communities, including those in the United States, as well as to Brazil. More recently, global ultra-Orthodox movements are gaining strength among the Jewish communities, under the impact of shlichim

2 Judith Laikin Elkin, The Jews of the Latin America $3^{\text {rd }}$ Edition (Boulder, CO: Lynne Rienner Publishers, 2014), 293. 
of Chabad Lubavitch or Latin American graduates of yeshivot in Israel and the United States. While large segments of the Jewish population are totally integrated into the Latin American environment, with a high percentage of intermarriage, the presence of ultra-Orthodox Jews, Ashkenazi and Sephardic, has been very visible in the public sphere from the 1980s on.

The growing role of religion in Jewish life has diminished the importance of Zionism as a manifestation of Jewish life-a phenomenon known as de-Zionization. Following its establishment, the State of Israel contributed to legitimizing local identities, and provided a respected madre patria for the rootless Jews. Gradually, however, Israel was transformed from a source of self-confidence to a source of danger, as manifested in the 1990s' bombings of the Israeli Embassy and the AMIA (Asociación Mutual Israelita Argentinathe Ashkenazi Jewish Community) in Buenos Aires, or in the anti-Semitic treatment of the Jewish community by the Chávez administration in Venezuela.

Political and economic crises in Latin American countries motivated waves of emigration that resulted in the emergence of transnational Jewish Latin American communities in Israel, the United States, and Europe. New problems now confronted the descendants of the immigrants who had found a haven from persecutions and poverty in Latin America. During the period of the military dictatorships, a relatively large number of Jews, particularly in Argentina, but also in Brazil, Chile, and Uruguay, were involved in underground activities. While many became Desaparecidos, others were able to escape to exile. At the same time that the countries of the Southern Cone experienced a return to democracy, other countries - such as Colombia, Peru, and Venezuela-faced political violence that threatened personal security, which became a major cause for emigration. In addition, the impoverishment of the middle classes under neo-liberal governments shattered the economic situation of the Jewish communities, leading to the departure of many Latin American Jews from Latin America.

Many of the early studies on Latin American Jewry were monographs prepared by local researchers, some academic, but many conducted by community activists, who wrote testimonies, memoirs, and histories of their own immigration and regions - works that came to light through books, magazines, and the community presses, and, in many cases, which were characterized by their apologetic tone.

One of the early initiatives to professionalize Jewish studies was the creation of the Program for Jewish Studies at the University of São Paulo in the late 1960s. 
xii | Introduction

During the same period, the Institute of Contemporary Jewry of the Hebrew University of Jerusalem introduced the study of Latin American Jewry with the pioneering studies of Haim Avni. The starting point for Avni’s approach was the need to understand the current existential problems of the Jews in Latin America through a combined analysis of the economic, social, and political reality in their respective countries, and the Jewish context at both the local and global levels.

Avni's students were among the founders of Agudat Mitmachei Iahadut Latinoamerica (AMILAT), an Israeli association of researchers of Latin American Jewry that organizes the Latin American section in the World Congresses of Jewish Studies, which take place every four years in Jerusalem. It also publishes the volumes of Judaica Latinoamericana, thus contributing to the inclusion of Latin America in the framework of Jewish studies.

While many of the early studies focused on one country, particularly Argentina, Judith Laikin Elkin was the first to present Latin American Jewry as a complex, pointing out the comparative perspective. Her book, The Jews in the Latin American Republics (1980), became the basic textbook for the study of Latin American Jewry in the United States. In 1980, she founded LAJSAthe Latin American Jewish Studies Association, which became an international forum for scholars interested in the field, with biannual conferences.

Latin American Jewish studies expanded gradually, with a growing crop of research, not only in history but also in literature, political science, sociology, anthropology, and art. Many of the researchers, particularly those based in the United States, became interested in the Jewish case from the perspective of general Latin American studies. A revisionist approach emerged, criticizing the "Zionist approach" of Haim Avni and his disciples. Its main representatives are Raanan Rein and Jeffrey Lesser, who argue that most of the old studies focus on the organized communities and ignore the nonaffiliated. They emphasize the local identity, using the term "Argentine Jews" instead of Jewish Argentineans, and stress the similarities between Jews and other minorities. ${ }^{3}$

This revisionist approach was challenged in Avni, Bokser Liwerant, DellaPergola, Bejarano and Senkman, Pertenencia y alteridad. Judíos en/de América Latina: Cuarenta años de cambios (Belonging and Otherness: Jews in/ from Latin America: Forty Years of Change) (2010), which makes a comparative

3 Jeffrey Lesser and Raanan Rein, eds., Rethinking Jewish-Latin Americans (Albuquerque: University of New Mexico Press, 2008); Ranaan Rein, Argentine Jews or Jewish Argentines (Leiden: Brill, 2010). 
analysis of both the history and the historiography of Latin American Jews between 1967 and 2008 .

\section{$* * *$}

The collection of articles in this volume is based on an international conference that took place in São Paulo in September 2012. The conference was organized in Israel by the Dahan Center of the Bar-Ilan University and the Academic College in Ashkelon, and, in Brazil, by The Program for Hebrew Language, Jewish Literature, and Culture, and the Center for Jewish Studies of the University of São Paulo. Half of the articles in the volume deal with Brazil, reflecting the growing importance of studies on Brazil in Latin American Jewish studies, thus contributing to a more proportionate balance between studies on Argentina, as the largest Jewish community, and Brazil, as the second.

In this collection, the reader will find a wide range of subjects reflecting all the historiographical approaches mentioned above, as well as various scholarly perspectives, such as social history, anthropology, sociology, and literary criticism. There are studies using comparison versus monographs; studies based on the inside perspective of the individual communities versus analyses of the Jewish case in the general context; papers focused on the Jewish communities versus those focused on the relationship between these groups - or the diasporas - and the State of Israel. The common denominator of all the works included in the present volume is the aim to understand the singularity of contemporary Judaism and Jewishness in Latin America.

Some of the articles reflect the way in which scholars of Jewish studies in Israel are exposed to subjects such as the emergence of the new orthodoxy, Jewish education in the Diaspora, aliyah, and kibbutzim, or to Latin American literature from an Israeli point of view. Indeed, both lay Israelis and the Israeli academic community continue to regard Latin America as an "exotic" and distant space studied almost exclusively by researchers from various academic institutes dedicated to Latin American studies or to Latin American Jewish studies. In their efforts to overcome this tendency, the contribution of Israeli authors to this volume is an important step in demystifying stereotypes that were consolidated in Israeli society over several decades. At the same time, they raise awareness of the importance of Latin America in the global context, and the relevance of the different Jewish communities and their special relations to the State of Israel. 
xiv | Introduction

We would like to extend our thanks and appreciation to Dr. Shimon Ohayon of the Dahan Center, for his support and encouragement over the years. Our thanks also go to Dr. Gabriel Steinberg, head of the Center for Jewish Studies of the University of São Paulo, for giving us the backing needed for the successful accomplishment of the conference; to our students, Amilkar Henrique Gonçalves de Moura and André Galvão Soares, who worked with enthusiasm and efficiency on the last-minute details; and, finally, to Robert Bánvölgyi, who did the simultaneous translation of conferences presented in Hebrew into Portuguese. Above all, we would like to thank Mrs. Ora Kobelkowsky, who, on an almost daily basis over more than three years, ably and painstakingly oversaw the editing of the articles. She was the connecting link between the contributors to this volume and us, and did it so graciously.

We hope that the contents of this volume will be of interest to both scholars and laypersons who care about Jewish life in Latin America.

Margalit Bejarano, Israel Yaron Harel, Israel Marta F. Topel, São Paulo 